\title{
Sero-prevalence of human immunodeficiency virus infection among patients with newly diagnosed pulmonary tuberculosis in a teaching hospital in Bauchi, North-Eastern Nigeria
}

\author{
Sabiu Abdu Gwalabe, ${ }^{1}$ Jacob Dunga, ${ }^{1}$ Yusuf Jibrin Bara, ${ }^{1}$ Alkali Muhammad, ${ }^{1}$ \\ Mustapha Sabo Umar, ${ }^{1}$ Sule Bathna ${ }^{2}$ \\ ${ }^{1}$ Department of Medicine, Abubakar Tafawa Balewa University Teaching Hospital, Bauchi, Bauchi State; \\ ${ }^{2}$ Department of Medicine, Federal Teaching Hospital, Gombe, Gombe State, Nigeria
}

\begin{abstract}
About a third of the human immunodeficiency virus (HIV) positive population worldwide is co-infected with Mycobacterium tuberculosis. However, data are lacking about the prevalence of HIV among patients with pulmonary tuberculosis (PTB) in a teaching hospital in Bauchi, northeast Nigeria. The aim of this study is to determine the sero-prevalence of HIV among patients with sputum smear positive PTB at Abubakar Tafawa Balewa University Teaching Hospital (ATBUTH), Bauchi, Bauchi State, Nigeria. This is a retrospective study review of patients' medical records diagnosed with sputum smear positive PTB that attended and received treatment at directly observed treatment short course (DOTS) clinic of Abubakar Tafawa Balewa University Teaching Hospital (ATBUTH), Bauchi, Bauchi State, North-Eastern Nigeria from January, 2015- December, 2017. All the patients were newly diagnosed with sputum smear positive PTB using ZN stain testing of their sputum and screened for HIV antibodies. There were 155 patients studied comprising of 95 (61.29\%) males and $60(38.71 \%)$ females. One hundred and twenty $(77.42 \%)$ patients were seronegative and $35(22.58 \%)$ sero-positive for HIV. Most of the
\end{abstract}

Correspondence: Gwalabe Sabiu Abdu, Department of Medicine, Abubakar Tafawa Balewa University Teaching Hospital, Bauchi, Bauchi State, Nigeria.

E-mail: sabiuag@yahoo.com

Key words: Sputum smear positive PTB; HIV sero-prevalence; NorthEastern Nigeria.

Acknowledgements: our special gratitude goes to the management, research and ethical committee of Abubakar Tafawa Balewa University Teaching Hospital, Bauchi, Bauchi State, Nigeria for granting us permission to carry out this study. We would also like to sincerely thank all our colleagues and other staff that contributed, reviewed and assisted in this study.

Conflict of interest: the authors declare no potential conflict of interest.

Received for publication: 30 May 2018.

Accepted for publication: 9 June 2018.

This work is licensed under a Creative Commons Attribution NonCommercial 4.0 License (CC BY-NC 4.0).

(C) Copyright S.A. Gwalabe et al., 2018

Licensee PAGEPress, Italy

Annals of African Medical Research 2018; 1:28

doi:10.4081/aamr.2018.28 patients were within the ages of 15-54 years with mean age of $34.63 \pm 15.55$. The sero-prevalence of HIV infection among the patients is $22.58 \%$. Sero-prevalence of HIV is observed to be high among young and married patients with secondary level of education.

The sero-prevalence of HIV infection among the patients is relatively lower than those reported in most parts of Nigeria and the sub-Saharan Africa, hence there is still need for continued screening of HIV antibodies among patients with PTB so as to reduce the morbidity and mortality that may result from the coinfection.

\section{Introduction}

More than two billion people (about one-third of the world population) are estimated to be infected with M. tuberculosis. ${ }^{1}$ The global incidence of tuberculosis (TB) peaked around 2003 and appears to be declining slowly. ${ }^{2}$ According to the World Health Organization (WHO) in 2015, 10.4 million individuals became ill with TB and 1.8 million died. ${ }^{2}$

About a third of the human immunodeficiency virus (HIV) positive population worldwide is co-infected with Mycobacterium tuberculosis. This accounts to about 14 million people worldwide. ${ }^{3}$ Tuberculosis is the largest single cause of death in the acquired immune deficiency syndrome (AIDS), ${ }^{4}$ accounting for about $26 \%$ AIDS related deaths, ${ }^{3}$ 99\% of which occur in developing countries. ${ }^{5}$ Globally, $9 \%$ of all TB cases in adults are attributed to HIV. ${ }^{4}$ Human immunodeficiency virus co-infection is the most powerful known risk factor for progression of Mycobacterium tuberculosis infection to active disease, increasing the risk of latent tuberculosis reactivation 20 -fold. ${ }^{3,6}$ Likewise TB has been reported to exacerbate HIV infection. , $^{7}$

HIV patients are highly vulnerable to TB because of their weakened immune systems and the latter is now their number one killer. Surveillance of HIV among TB patients has been recognized as important as the HIV epidemic continues to fuel TB epidemics. Reports show that in Sub-Saharan Africa, HIV sero-prevalence rates among TB patients range from $24-67 \%$, while lower rates of $0.4-20.1 \%$ was reported from India, ${ }^{9} 3.7 \%$ in San Francisco ${ }^{10}$ $30.0 \%$ in Trinidad and Tobago, ${ }^{11} 28.2 \%$ in Guyana, ${ }^{12} 9.9 \%$ in Cambodia, $^{13} 23.6 \%$ in Florida ${ }^{14}$ and $10.8 \%$ in Southwest Guatemala. ${ }^{15}$ Among European countries, France, Iceland and Portugal have reported co-infection prevalence of approximately $11-15 \%$, but central European countries have reported a lower prevalence $(0-1 \%){ }^{16}$

Many studies have been done in parts of Nigeria on prevalence of HIV among TB patients with prevalence of $18.8 \%$ in Kano, ${ }^{17}$ $28.12 \%$ in Ibadan $^{18}$ and $48 \%$ in North-Central, Nigeria. ${ }^{19}$ 
However, data are limited on the prevalence of HIV among patients with pulmonary tuberculosis (PTB) in a teaching hospital in Bauchi, Northeastern, Nigeria. The aim of this study is to determine the sero-prevalence of HIV among patients with sputum smear positive PTB at ATBUTH, Bauchi, Bauchi State, Nigeria. The finding of the study will possibly provide baseline data to alert the TB control programs of the potential HIV problems with a view to the development of joint strategies. More so that antituberculosis treatment has been shown to be complicated by frequent drug interactions with highly active antiretroviral therapy (HAART) and adverse drug reactions are more common among HIV-infected patients. ${ }^{9}$

\section{Materials and Methods}

This is a retrospective study review of patients diagnosed with sputum smear PTB that attended and received treatment at the TB directly observed treatment short course (DOTS) clinic of ATBUTH, Bauchi, Bauchi State, Northeastern Nigeria from January, 2015- December, 2017. The hospital is a 750-bed tertiary health care facility that provides specialist services and served as a major referral center in Northeast region of Nigeria and other neighboring states.

All the patients were newly diagnosed with sputum smear positive PTB using ZN stain testing of their sputum and screened for HIV-antibodies using Determine and confirmed if reactive by Unigold. Data were extracted from the patients' medical records and treatment cards by using a structured data extraction form. Information retrieved from the records included the age, sex, marital status, educational level and occupation of the patients. The extraction of patient's details from the record was done by the TB DOTS health officers.

Permission to carry out the study was obtained from the research and ethical committee of ATBUTH, Bauchi, Bauchi State, Northeastern Nigeria. Socio-demographic variables of the patients were entered into the study database and analyzed using SPSS version 18.0 (SPSS, Ill., Chicago, USA). The values were expressed in frequencies and percentages. Sero-prevalence of HIV among the patients was determined by the percentage of the total number of patients were sero-positive for HIV. Tables were used for illustration. Comparison of means was done with the Student's $t$-test. Chisquare $\left(\chi^{2}\right)$ was also been used to determine the difference in some variable. A $P$ value of $<0.05$ was considered statistically significant.

\section{Results}

There were 155 patients studied comprising of 95 (61.29\%) males and $60(38.71 \%)$ females. Their ages range from 15-94 years. Most of the patients $(90.32 \%)$ were within the ages of 15-54 years. The mean age \pm standard deviation (SD) of the patients was $34.63 \pm 15.55$. There is no significant difference between the mean age of males and that of females $34.31 \pm 13.12$, 35.15 \pm 18.82 respectively $(\mathrm{P}=0.74)$. Likewise there is no statistically significant difference between the mean ages of those that are sero-negative and those that are sero-positive $34.23 \pm 16.82,36.03 \pm 10.07$ respectively $(\mathrm{P}=0.54)$. None of the patients above or equal to 65 years of age is sero-positive for HIV. The sero-prevalence of HIV among the patients is $22.58 \%$ (Table 1 ).

Table 2 shows that out of the total 95 males, 78 (50.32\%) were sero-negative and $17(10.97 \%)$ sero-positive. Out of the total 60 females $42(27.10 \%)$ were sero-negative and 18 (11.61\%) seropositive. There is no statistically significant difference in HIV sero-positive males $v s$ females [Chi Square $\chi^{2}=3.083 \mathrm{df}=1$ $(\mathrm{P}=0.079)]$.

Sixty-two (40.00\%) patients were single, 89 (57.42\%) were married and $4(2.58 \%)$ widows. Among those that were sero-negative for HIV, 57 (36.77\%) were single, 60 (38.71\%) were married and $3(1.94 \%)$ were widow. Among those that were sero-positive for HIV, 5 (3.23\%) were single, 29 (18.71\%) were married and 1 $(0.64 \%)$ was a widow. This shows that co-infection is high among married patients (Table 3 ).

Table 4 shows educational level of the patients. Among those

Table 1. Age and HIV status distribution of the patients.

\begin{tabular}{lccc}
$\begin{array}{l}\text { Age } \\
\text { group }\end{array}$ & HIV sero-negative & HIV sero-positive & Total \\
$\mathbf{N}(\%)$ & $(\%)$ & $\mathbf{N}(\%)$ \\
$15-24$ & $41(26.45)$ & $3(1.94)$ & $44(28.39)$ \\
$25-34$ & $35(22.58)$ & $13(8.39)$ & $48(30.97)$ \\
\hline $35-44$ & $18(11.61)$ & $10(6.45)$ & $28(18.06)$ \\
$45-54$ & $12(7.74)$ & $8(5.16)$ & $20(12.90)$ \\
\hline $55-64$ & $4(2.58)$ & $1(0.64)$ & $5(3.23)$ \\
$65-74$ & $5(3.23)$ & $0(0.00)$ & $5(3.23)$ \\
\hline $75-84$ & $3(1.94)$ & $0(0.00)$ & $3(1.94)$ \\
$85-94$ & $2(1.29)$ & $0(0.00)$ & $2(1.29)$ \\
\hline Total & $120(77.42)$ & $35(22.58)$ & $155(100)$ \\
\hline
\end{tabular}

Table 2. Sex and HIV status distribution of the patients.

\begin{tabular}{lccc} 
Sex & HIV sero-negative & HIV sero-positive & Total \\
$\mathbf{N}(\%)$ & $\mathbf{N}(\%)$ & $\mathbf{N}(\%)$ \\
Male & $78(50.32)$ & $17(10.97)$ & $95(61.29)$ \\
Female & $42(27.10)$ & $18(11.61)$ & $60(38.71)$ \\
\hline Total & $120(77.42)$ & $35(22.58)$ & $155(100)$ \\
\hline
\end{tabular}

is no significant difference in HIV sero-positive males $v$ s females [Chi Square $\chi^{2}=3.083 \mathrm{df}=1$ $(\mathrm{P}=0.079)]$.

Table 3. Marital and HIV status of the patients.

\begin{tabular}{lccc}
$\begin{array}{l}\text { Marital } \\
\text { status }\end{array}$ & HIV sero-negative & HIV sero-positive & Total \\
N $(\%)$ & N (\%) & N (\%) \\
Single & $57(36.77)$ & $5(3.23)$ & $62(40.00)$ \\
Married & $60(38.71)$ & $29(18.71)$ & $89(57.42)$ \\
Widow & $3(1.94)$ & $1(0.64)$ & $4(2.58)$ \\
Total & $120(77.42)$ & $35(22.58)$ & $155(100)$ \\
\hline
\end{tabular}

Table 4. Educational level and HIV status distribution of the patients.

\begin{tabular}{lccc}
$\begin{array}{l}\text { Education } \\
\text { level }\end{array}$ & HIV sero-negative & HIV sero-positive & Total \\
N $(\%)$ & $\mathbf{N}(\%)$ & $\mathbf{N}(\%)$ \\
Primary & $13(8.39)$ & $4(2.58)$ & $17(10.97)$ \\
Secondary & $48(30.97)$ & $20(12.90)$ & $68(43.87)$ \\
\hline Tertiary & $48(30.97)$ & $7(4.52)$ & $55(35.49)$ \\
None & $11(7.09)$ & $4(2.58)$ & $15(9.68)$ \\
\hline Total & $120(77.42)$ & $35(22.58)$ & $155(100)$ \\
\hline
\end{tabular}


that were sero-negative, $13(8.39 \%)$ attained primary education, 48 (30.97\%) attained secondary, $48(30.97 \%)$ also attained tertiary level and $11(7.09 \%)$ had no education. Among those that were sero-positive, $4(2.58 \%)$ attained primary education, $20(12.90 \%)$ attained secondary level, $7(4.52 \%)$ attained tertiary level and 4 $(2.58 \%)$ had no formal education.

Table 5 shows occupational status of the patients. Among those that were sero-negative, $14(9.03 \%)$ were self-employed, 12 (7.74\%) unemployed, $11(7.09 \%)$ were doing business, 29 (18.71\%) civil servants, $31(20.00 \%)$ students, 6 (3.87\%) farmers and $17(10.97 \%)$ housewives. Among those that were sero-positive, $4(2.58 \%)$ were self-employed, $5(3.23 \%)$ unemployed, 2 (1.29\%) were doing business, 8 (5.16\%) civil servants, $3(1.94 \%)$ students, $2(1.29 \%)$ farmers and $11(7.09 \%)$ housewives.

\section{Discussion and Conclusions}

The sero-prevalence of HIV infection among the patients is $22.58 \%$. This is slightly higher than that reported Yusuf et al. of $18.8 \%$ in Kano, ${ }^{17}$ North-Western, Nigeria, but lower than that reported by Ige et al. in Ibadan, South-western, Nigeria of $28.12 \%,{ }^{18}$ Mbaave et al. of $48 \%{ }^{19}$ in North-Central, Nigeria and by Corbett et al. of $38 \%$ in sub-Saharan Africa. ${ }^{4}$ This variation in the prevalence could be due to difference in location of the study as the prevalence of HIV infection has been reported to have geographical variation in several other African studies. ${ }^{20}$

The mean age of the patients of $34.63 \pm 15.55$ is similar to that reported in Nguru by Yusuf et al. ${ }^{21}$ and Gwalabe et al. in Maiduguri $^{22}$ all in North-Eastern, Nigeria. The involvement of relatively younger people may among others, be due to exposure to predisposing risk factors for PTB such as sustained contact with people having PTB early in life. ${ }^{23}$ Most of the patients studied were within the ages of 15-54 years. Patients in these groups by virtue of their vigorous adventurism and survival pursuits are exposed to more infection by contact. This explains why TB is a problem of people below 50 years in our population. Joel and Nicholas in Kenya reported that $97 \%$ of persons affected by TB come from the economically productive age ( $15-50$ years). ${ }^{24}$ This age group is sexually active and most at risk of HIV infection. None of the patients above or equal to 65 years old is found to be sero-positive for HIV and hence, younger age is a significant risk factor for acquiring HIV infection among the patients. This is consistent with findings in Nigerian study ${ }^{25}$ and in a previous African study. ${ }^{26}$

There is predominance of males in the study with males to

Table 5. Occupation and HIV status of the patients

\begin{tabular}{lccc} 
Occupation & HIV sero-negative & HIV sero-positive & Total \\
N (\%) & \% & N (\%) \\
Self-employed & $14(9.03)$ & $4(2.58)$ & $18(11.61)$ \\
Unemployed & $12(7.74)$ & $5(3.23)$ & $17(10.97)$ \\
\hline Business & $11(7.09)$ & $2(1.29)$ & $13(8.38)$ \\
Civil servant & $29(18.71)$ & $8(5.16)$ & $37(23.87)$ \\
\hline Student & $31(20.00)$ & $3(1.94)$ & $34(21.94)$ \\
Farmer & $6(3.87)$ & $2(1.29)$ & $8(5.16)$ \\
\hline Housewife & $17(10.97)$ & $11(7.09)$ & $28(18.06)$ \\
Total & $120(77.42)$ & $35(22.58)$ & $155(100)$ \\
\hline
\end{tabular}

female ratio of 1.58:1.00. This finding is slightly higher than those reported by Ige et al. of 1.16:1.00 ${ }^{18}$ and Raviglione et al. ${ }^{27}$ globally of 1.2:1. There is no statistically significant difference in HIV seropositive males $v s$ females [Chi Square $\left.\chi^{2}=3.083 \mathrm{df}=1(\mathrm{P}=0.079)\right]$, hence gender is not a significant factor in this study for TB/HIV co-infection. This is similar to the findings reported by Oladeinde et al. ${ }^{20}$ and Ejikeme et al. ${ }^{28}$ This is most likely, because most of the patients both males and females were young in their reproductive age group and have high risk for both TB and HIV infections.

The educational status of the patients as shown in Table 4, most of them were educated with secondary and tertiary level of education, even among those that were sero-positive for HIV; most of them have attained secondary level of education. This finding is not similar to those reported by Oladeinde et al. ${ }^{20}$ where educational status is not a risk factor for TB/HIV co-infection. This is probably could be due to higher level of awareness among the educated ones in our locality to seek for prompt medical treatment.

In terms of occupation of the patients, most of them were civil servants and students as shown in Table 5. This is contrary to the finding reported by Yusuf et al. ${ }^{17}$ in Kano, where unemployed people were the majority of their patients. The possible explanation for this disparity is difference in localities of the studies areas.

In conclusion, the sero-prevalence of HIV infection among the patients is relatively lower than those reported in most parts of Nigeria and the sub-Saharan Africa, hence there is still need for continued screening of HIV antibodies among patients with PTB so as to reduce the morbidity and mortality that may result from the co-infection.

\section{References}

1. Dheda K, Barry CE 3rd, Maartens G. Tuberculosis. Lancet 2016;387:1211-26.

2. World Health Organization. Global Tuberculosis Report, 2016. WHO, Geneva 2016. Available from: http://apps.who.int/iris/bitstream/10665/250441/1/978924156 5394-eng.pdf?ua=1 Accessed: November 08, 2016.

3. Getahun H, Gunneberg L, Granich R, Nunn P. HIV infectionassociated tuberculosis: the epidemiology and the response. Clin Infect Dis 2010;50:S201-7.

4. Corbett EL, Watt CJ, Walker N, et al. The growing burden of tuberculosis: global trends and interactions with the HIV epidemic. Archiv Intern Med 2003;163:1009-21.

5. Collins KR, Quinones-Mateu ME, Toosi Z, Arts EJ. Impact of tuberculosis on HIV-1 replication, diversity and disease progression. AIDS Rev 2002;4;165-76.

6. Selwyn PA, Hartel D, Lewis VA, et al A progressive study of the risk of tuberculosis among intravenous drug users with HIV infection. N Engl J Med 1989;320:545-50.

7. Whalen C, Horsburg CR, Horn D, et al. Accelerated course of HIV infectionafter tuberculosis. Am J Respir Crit Care Med 1995;151:129-35.

8. Modjarad K, Vermund SH. Effect of treating co-infection on HIV-1 viral load: a systematic reviw. Lancet Infect Dis 2010;10:455-63.

9. Sharma SK, Mohan A, Kadhiravan T. HIV-TB co-infection: epidemiology, diagnosis and management. Indian J Med Res 2005;121:550-67.

10. De Riemer K, Kawamura LM, Hopewell PC, Daley CI. Quantitative Impact of HIV Infection on TB Dynamics. Am J Crit Care Med 2007;176:936-44.

11. Babool S, Millet J, Akpaka PE, et al. First insight into m. tuber- 
culosis, epidemiology and genetic diversity in Trinidad and Tobago. J Clin Micr 2009;47:1911-4.

12. Kaiser Global Health Report.Org. Increase in HIV coinfection leads to increasing TB prevalence in Guyana; Nov. 26, 2008. Available from: www.kaisernetwork.org/dailyreports/index.cfin?DR ID=5576 0

13. Tamura M, Eam KK, Yoshihara N, et al. National HIV prevalence among TB patients through periodic survey: experience in Cambodia. Int J Tuberc Lung Dis 2008;12:520-5.

14. Lalota M, Schultz JM, Gracia LM, et al. HIV seroprevalence and risk behaviours among clients attending TB clinics in Miami-Dade County, Florida, 1989-1996. Pop Res Policy Revs 2004;20:253-66.

15. Tellez CA, Ikeda JM, Cohen BE, et al. Int Conf AIDS 2004;14:abstract no. C10989,2002.

16. Giehl C, Roy RB, Knellwolf AL. The situation of HIV/M.tuberculosis co-infection in Europe. Open Infect Dis J 2011;5:21-35.

17. Yusuf M, Azeez-akande O, Yusha'u M. HIV seroprevalence among adult with newly diagnosed pulmonary tuberculosis in Kano, Nigeria. J Med Trop 2013;5:140-3.

18. Ige OM, Sogaolu OM, Ogunlade OA. Pattern of presentation of tuberculosis and the hospital prevalence of tuberculosis and immunodeficiency virus co-infection in university college hospital, Ibadan. A review of five years (1999-2004). Afr J Med Sci 2005;34:329-33.

19. Mbaave TP, Igbudu TJ, Egwuda I, et al. GeneXpert MTB/Rif sputum MTB detection and HIV seroprevalence among patients with presumptive pulmonary tuberculosis at a new Teaching hospital in Nort-Central, Nigeria. Int J Curr
Microbiol App Sci 2016;5:564-70.

20. Oladeinde BH, Olley M, Imade OS, Onifade AA. Prevalence of HIV infection among patients with pulmonary tuberculosis in a rural tertiary hospital in Nigeria. Niger J Exp Clin Biosci 2014;2:90-4.

21. Yusuf H, Zailani SB, Ahedjo A. Prevalence of HIV in Tuberculosis patients in Nguru, North-eastren, Nigeria. Sahel Med J 2005;8:65-7.

22. Gwalabe SA, Yusuph H, Mustapha SK, et al. Tuberculin skin test and serum albumin among sputum smear positive pulmonary tuberculosis patients in Maiduguri, Nigeria. Bo Med J 2014;11:106-10.

23. Lienhardt C, Fielding K, Sillah J, et al. Risk factors for tuberculosis infection in Sub-Saharan Africa: a contact study in Gambia. Am J Respir Crit Care Med 2003;168:448-55.

24. Joel KK, Nicholas KK. The re-emergence of tuberculosis among the economically productive age group in Kenya: the case of Mombasa district. J Soc Dev Afr 2003;18:121-32.

25. Pennap G, Makpa S, Ogbu S. Sero-prevalence of HIV infection among tuberculoisis patients in a rural tuberculosis referral clinic in Northern, Nigeria. Pan Afr Med J 2010;5:22.

26. Toban H, Doherty T, Swarevelder S, et al. Knowledge of HIV status prior to a community HIV couselling and testing intervention ia a rural district of South Africa. Results of a community based survey. BMC infect Dis 2012;12:73.

27. Raviglione MC, Harries AD, Msiska R, et al. Tuberculosis and HIV. Current status in Africa. AIDS 1997;11:S115-23.

28. Ejikeme N, Godwin AP. Prevalence of Mycobacterium tuberculosis and HIV infections in Umahia, Abia state, Nigeria. Afr J Micobiol Res 2010;4:1486-90. 